\title{
Influencing Motivation In The Foreign Language Classroom
}

\author{
Simon James Nicholson, Hankuk University of Foreign Studies, South Korea
}

\begin{abstract}
Motivation is one of the main determining factors of success in developing a second or foreign language. However, motivation is a complex phenomenon and the more its constructs are understood the better we are able to understand the extent to which we can influence it. Teachers can cultivate student motivation to varying degrees and play a central role in activating and sustaining it. This paper identifies the components that influence student motivation in language learning and proposes ways in which teachers can improve levels of motivation in the classroom and the extent to which these measures are effective.
\end{abstract}

Keywords: Integrative Motivation; Instrumental Motivation; Intrinsic Motivation; Extrinsic Motivation; SelfDetermination Theory; Ideal Self; Learner Autonomy

\section{INTRODUCTION}

s most teachers of a foreign language can attest to, the level of a student's motivation plays a central role in their foreign or second language learning and acquisition. Although there is no empirical evidence to prove that motivation leads to a successful outcome, it is accepted that motivation is one of the main determining factors of success in developing a second or foreign language. The difficulty for educators and researchers is in trying to capture the construct of motivation for clearly it is a complex phenomenon (Scheidecker and Freeman 1999). That being said, the more these constructs are understood, the better we, as teachers, are able to see the extent to which we can exert influence and be in a better position to improve motivation in our students.

The purpose of this paper is to first explore predominant motivational theories in the SLA literature. From this examination the author will then proceed to identify key factors that motivate someone to learn a foreign language. The writer will then propose the manner in which teachers or language advisors can improve levels of motivation in their students and consider the extent to which this improvement can be accomplished.

\section{PREDOMINANT MOTIVATIONAL THEORIES IN SLA}

For the purposes of this paper it is first necessary to examine predominant motivational theories found in the SLA literature in order to identify the key components that influence student motivation in the L2 classroom.

\subsection{The Integrative- Instrumental Dichotomy}

The earliest theories of motivation assumed that the forces that give energy and direction to student behavior were beyond the teachers' control or influence. These theories, which became integral to modern motivational SLA research, were first developed by Gardner and Lambert in 1959. They proposed that students' motivation could be classified into two distinct orientations: integrative and instrumental (Gardner and Lambert 1959).

Integrative orientation deals with the student's motivation to learn the language for reasons such as interest in foreign languages, desire for interaction with the target language community, and attitudes toward the target language community (Gardner \& Lambert 1972). That is, their motivations are socially and culturally orientated to 
integrate themselves into the culture of the second language group and become involved in social interchange within that group. Gardner noted that within this orientation there exists "a high level of drive on the part of the individual to acquire the language of a valued second language community in order to facilitate communication with that group" (Gardner et al. 1976: 199).

Integrative motivation is the most often researched concept of SLA motivational literature and has lead researchers to conclude that "integrativeness appears to be the single most important factor" of L2 acquisition (Csizer \& Dornyei 2005:19) as studies and research show "that learners ranking high on integrative orientation work harder and learn faster than those who are low on integrative motivation" (Clement et al. 1994; Gardner, Lalonde \& Pierson 1983; Gardner, Lalonde \& Moorcroft 1985; Gardner, Lalonde, Moorcroft, \& Evers 1987; Gardner, Moorcrfoft \& Metford 1989; Gardner \& MacIntyre 1991; Lai 2000; Masgoret \& Gardner 2003; Trembley \& Gardner 1995; cited in Lui 2007: 127).

On the other hand, instrumental orientation deals with the practical advantages of learning an L2. As Brown points out, the instrumental side of the integrative- instrumental dichotomy refers to "acquiring a language as a means for attaining instrumental goals: furthering a career, reading technical material, translation, and so forth" (2000: 162). Within the construct of instrumental orientation, acquisition of the L2 can be seen as necessary for pragmatic gains such as getting a better job or a higher salary (Dornyei 2001; Gardner \& Lambert 1972).

\subsection{The Intrinsic-Extrinsic Factor}

As motivational research developed it became clear that the classifications of motivation were far more complex. Though strongly influenced by forces outside of the individual (see section 2.1), the manner in which those forces were internalized by the individual and woven into their perceptions of self greatly influenced their levels of motivation for learning the L2. This gave rise to cognitive views, which "stress that human behavior is influenced by the way people think about themselves and their environment," (Biehler \& Snowman 1997:402) and this influences their decision to act.

Intrinsic motivation founds its basic principles on the assumption that humans are active beings in need of autonomy and with an innate curiosity (Deci and Ryan, 1985; Ryan and Deci, 2000; Ushioda, 1996; Ushioda, 2003). Intrinsic motivation is present when learners actively seek out and participate in activities without having to be rewarded by materials or activities outside the learning task. Intrinsic motivation refers to tasks that are rewarding in and of themselves, such as the pleasure of solving a puzzle, learning, or playing a game: the motivating factors for taking such actions are not external, but internal.

The following are characteristic of an intrinsically motivated student:

- Intrinsically motivated students retain information and concepts longer and are less likely to need remedial courses and review (Dev 1997).

- Intrinsically motivated students are more likely to be lifelong learners, continuing to educate themselves outside the formal school setting long after external motivators such as grades and diplomas are removed (Kohn 1993).

- Intrinsically motivated students engage actively in activities without having to be rewarded. These learners persist until they accomplish a task successfully (Oxford and Shearin 1994; Noels et al. 2001).

Unlike intrinsic motivation, extrinsic motivation involves engaging in a task due to external factors. This can mean working for money and food, or it can involve taking actions to avoid harm. As Dornyei explains, "extrinsic motivation refers to behaviors that 'the individual performs to receive some extrinsic reward' such as getting good grades, being praised by the teacher or to avoid punishment" (Dornyei 1994a: 275). This motivational type shares some similarities with instrumental orientation (see 2.1) in that in both cases students are driven to perform as a reaction to some external objective (personal gain, reward, etc.) (Noels, et al. 2003). 


\subsection{Self Determination Theory}

Self-determination theory (SDT) highlights the importance of "humans' evolved inner resources for personality development and behavioral self-regulation" (Ryan and Deci 2000: 68). Within this construct two motivational types are at play: extrinsic and intrinsic motivation (Dornyei 2003, Noels et al. 2003). However, instead of viewing these motivations as being categorically different, SDT views these factors as lying along a continuum of self-determination where, through the process of self-regulation, extrinsic contingencies are progressively transformed into intrinsic (self-determined) values and motivations (Noels et al. 2003).

Extrinsic motivation according to self-determination theory can be broken down into the following four constructs:

- $\quad$ External regulation: This regulation represents reasons for performing an activity that are externalized. These behaviors are the least autonomous and are performed to satisfy an external demand or reward contingency (Ryan \& Deci 2000). For example, a student who works hard to learn an L2 solely for the purpose of acquiring a course credit or gaining a teachers praise would be described as externally regulated.

- Introjected regulation: This regulation represents reasons for performing an activity that are somewhat externalized. This behavior involves "taking in a regulation but not fully accepting it as one's own" (Ryan \& Deci 2000: 72) and is performed to demonstrate ability or to maintain feelings of worth. For example, this could include the student who does his or her homework to avoid feelings of guilt or failure or to impress others with their proficiency.

- Identified regulation: This regulation represents reasons for performing an activity that are somewhat internalized. This involves the conscious valuing of a behavioral goal or regulation such as that the action is accepted or owned as personally important (Ryan \& Deci 2000). For example, "language learners who feel that L2 fluency is an important aspect of their educational development will endure repetitive oral exercises in the interest of obtaining this level of competence" (Noels et al. 2003: 39-40).

- Integrated regulation: This regulation represents reasons for performing an activity that are wholly internalized and is the most autonomous form of extrinsic motivation. As per Ryan \& Deci, "Integration occurs when identified regulations are fully assimilated to the self" (Ryan \& Deci 2000: 73). For example, an individual performs an activity because he or she personally views the activity as worthwhile.

Deci and Ryan (1985) contend that self-determination theory reintroduces a component of motivation that has long been neglected by most modern cognitive motivational theories: psychological needs. Self-determination theory focuses on the three following needs, which appear to enhance intrinsic motivation (Ryan \& Deci 2000):

- $\quad$ Competence: feeling capable of learning English well.

- $\quad$ Relationships/Relatedness: feeling welcome from the teachers and English speaking community.

- Autonomy: feeling that English is chosen by the student rather than imposed.

According to this framework, social environments (i.e. the classroom) can facilitate intrinsic motivation by supporting the above psychological needs in students (Ryan \& Deci 2000).

It is clear that SDT attempts to address the more dynamic nature of motivation through its focus on regulation and psychological needs. Self-determination theory is perhaps best surmised by Dornyei who states,

"we will be more motivated to do something out of our own will than something we are forced to do (selfdetermination theory)" (2001: 12).

\section{$2.4 \quad$ The Ideal Self}

Recently, motivational theories have been developed to include the Ideal Self, a notion developed by Dornyei $(2005,2009)$ that attempts to reframe motivation in the context of contemporary notions of self and identity. According to Dornyei's Motivational Self-System, motivation comes about from the student's desire to lessen the gap between their actual self and their ought to self (see below) (Kormos and Csizer 2008). The theory is broken down into three components (Csizer and Dornyei 2005; Dornyei 2005, 2009; Kormos and Csizer 2008): 
- The Ideal L2 Self: The representation of all the attributes that a person would like to possess (e.g. hopes, aspiration, desires). If a student's ideal self is associated with the mastery of an L2 and engaging with the L2 community, that is, if the person that the student would like to become is active and proficient in the L2, he/she can be described - using Gardner's terminology - as having an 'integrative' disposition (Dornyei 2005).

- Ought-to L2 Self: The attributes that one believes one ought to possess to avoid possible negative outcomes, and which therefore may bear little resemblance to the person's own desires or wishes (Dornyei 2005). This includes one's perception of what significant others would like one to become. This learner could be described as being extrinsically motivated (see section 2.2) by instrumental values (Kormos and Csizer 2008).

- L2 Learning Experience: The attributes that are concerned with executive motives related to the immediate learning environment and experience (Dornyei 2005).

According to Gardner, Dornyei’s Motivational Self-System:

...tries to answer the challenge that the changing world of the $21^{\text {st }}$ century poses for the Gardenarian concept of integrativeness, the notion of the native speaker, and learners identification with native speakers (Gardner 1985, 2001; cited in Kormos \& Csizer 2008: 328).

In other words, this theory examines how to address motivation in a globalized community of which English is the lingua franca and where concepts of the L2 community have drastically changed. Identification solely with native speakers no longer seems to be a relevant motivating factor (Kormos and Csizer 2008) in learning an L2; rather, the scope of integrativeness should be looked at within the larger framework of the Ideal L2 Self (Higgins 1987; Markus and Nurius 1996; cited in Csizer and Dornyei 2005) in which English is associated with a global culture (Csizer and Dornyei 2005) rather than a national cultural base as with earlier models of integrativeness (Gardner 1972).

\section{KEY FACTORS}

Having examined the major theories of motivation from the SLA literature, the author will now identify certain key factors, which seem to play a central role in motivating students in learning a foreign language.

\subsection{Integrativeness and the Ideal L2 Self}

In both Gardner's (1972) and Dornyei's (2005, 2009) motivational models, the degree to which a student wants to engage with, or form part of, the L2 community (whether it be global or national) is a central motivating factor in L2 learning. Gardner and Lambert (1972) found that an integrative orientation accompanied higher scores on proficiency tests and this lead them to state that "motivation to learn a second language is grounded in positive attitudes toward the second language community and in a desire to communicate with valued members of that community" (cited in Liu 2007: 126). It is considered by many that integrative orientation, "is a better support for language learning" as opposed to instrumental orientation, which is associated "with a desire to learn [the] L2 for pragmatic gains" (Dörnyei 2001; Gardner \& Lambert 1972; cited in Liu 2007: 127).

In Dornyei's Motivational Self-System, the Ideal L2 Self is a developed form of Gardner's integrative orientation, but it has evolved to include more globalized notions of who comprises the L2 speaking community. As Dornyei states:

If the person we would like to become speaks an L2, the 'ideal L2 self' is a powerful motivator to learn the L2 because we would like to reduce the discrepancy between our actual and ideal selves (Dornyei 2009, cited in Murray, Gao \& Lamb 2011: 76).

This is a particularly powerful motivator as the definition of the L2 (English) speaker that much of Gardner's earlier research was based on has changed. No longer is the English language speaker limited to the United Kingdom, the United States, Canada and Australia. The second language community is now comprised of a 
cosmopolitan community of international L2 speakers, a group that students intend to become members of (Kormos and Csizer 2008).

\subsection{The Enjoyment of Learning}

Another key factor that motivates students to learn a language is the degree to which they are intrinsically motivated. "Intrinsically motivated students learn an L2 because of the inherent pleasure in doing so" (Oxford \& Sharon 1994; Noels et al. 2001; cited in Liu 2007: 128), and it is this intrinsic motivation that leads students to maintain their effort and engagement in the L2 learning process. As Ramage (1990) found, "continuing [language learning] students were more motivated to learn language for language's sake - that is, they were more intrinsically motivated" (cited in Noels et al. 2003: 40). Thus, the role that intrinsic motivation plays in language learning is significant as continued effort and study on the part of the student help to facilitate L2 learning and acquisition.

\subsection{External Pressures}

The final key factor in L2 motivation is the presence of external pressures and their influence on the language learner. As stated by Noels et al. (2001), this extrinsic motivation "refers to the desire to learn a second/foreign language because of some pressure or reward from the social environment (such as career advancement of course credit)" (cited in Liu 2007: 128). In many cases, without these forms of external pressure, many students will discontinue their language study. As Liu found in China, "after English courses become selective...the majority of the students stop taking any of them.... Because of the absence of pressure, most students stop making efforts to learn the language" (Liu 2007: 130). As noted by Ramage (1990), "Discontinuing students [of L2 studies] had a stronger interest in language learning as a means to other goals (e.g. academic credit)" (cited in Noels et al. 2003: 40). In other words, once these external pressures are removed, there is little motivation to continue the pursuit of L2 learning for many language learners.

\section{IMPROVING LEVELS OF MOTIVATION}

Having identified certain key factors central to motivating students to learn a foreign language, the following section will propose ways in which teachers can improve levels of motivation in the L2 classroom by focusing on these factors.

\subsection{Intrinsic Factors}

Throughout the literature intrinsic motivation is cited as playing an important role in relation to students' L2 learning (Brown 2000; Ramage 1990; Crookes \& Schmidt 1991; Dornyei 1998; Csizer \& Dornyei 2005; Noels et al. 1999, 2001; Pae 2008) as it is strongly associated with continued L2 study as well as long-term retention (Ramage 1990; Oxford \& Sharon 1994; Noels et al. 2001; Brown 2000; Liu 2007). Therefore, it would seem that focusing on intrinsic factors within the classroom could be an effective way of improving levels of motivation of foreign language learners.

\subsubsection{Relevant Materials and Activities}

Kormos and Csizer (2008) note, "It is evident that teachers' materials and activities are instrumental in shaping attitudes to learning" (p. 350). This sentiment is echoed by Pae (2008) who recommends that teachers devise learning activities that are intrinsically motivating for the students and which subsequently meet students' needs. Lightbrown and Spada believe that:

Teachers can make a positive contribution to students' motivation to learn if classrooms are places that students enjoy coming to because the content is interesting and relevant to their age and level of ability (2006: 64).

Therefore, it is evident that the extent of a teacher's influence on these particular intrinsic factors is significant. By selecting materials and activities relevant to students' interests and needs, teachers can go a long way in shaping students' attitude towards L2 learning. 


\subsubsection{Increase Learner Confidence}

An integral component to L2 motivation is learner confidence and there are various strategies the teacher can employ to help increase learner confidence in the classroom. As Pae suggests, "Intrinsic motivation should be promoted in a way that maximizes learners' self-confidence and motivation, which in turn will bring about increased L2 achievement" (2008: 23). In Dornyei's (1994a: 281) breakdown of how to motivate L2 learners, he suggests that teachers can develop students' self-confidence by engaging in the following behaviors:

- $\quad$ Trusting students and projecting the belief that they can achieve their goal.

- $\quad$ Regularly providing praise, encouragement and reinforcement.

- $\quad$ Ensuring students regularly experience success and a sense of achievement.

- Helping to remove uncertainties about their competence and self-efficacy by giving relevant positive examples and analogies of accomplishment.

- Counterbalancing experiences of frustration by involving students in more favorable, "easier" activities.

- Using confidence-building tasks in the classroom.

\subsubsection{Fostering Learner Competence}

As reviewed in section 2.3, competence is considered to be a fundamental psychological need, which, if met, can greatly enhance the intrinsic motivation of a student (Ryan and Deci 2000). This can be achieved through the social-contextual events of the classroom including feedback, communication and rewards (Ryan and Deci 2000). Dornyei (1994a: 281) identifies other ways in which teachers can promote favorable self-perceptions of competence in their students. He cites the following:

- $\quad$ Highlighting what students can do in the L2 rather than what they cannot do.

- $\quad$ Encouraging the view that mistakes are part of learning.

- $\quad$ Pointing out that there is more to communication than accuracy.

- $\quad$ Talking openly about teacher shortcomings in foreign language learning.

\subsubsection{Fostering Learner Autonomy}

As noted by Ryan \& Deci (2000), "Feelings of competence will not enhance intrinsic motivation unless accompanied by a sense of autonomy" (p. 70). Therefore, teachers can further increase students' intrinsic motivation by fostering learner autonomy in the classroom as "field studies have...shown that teachers who are autonomy supportive catalyze in their students greater intrinsic motivation, curiosity, and desire for challenge" (Deci, Nezlek \& Sheinman 1982; Flink, Noggiano, \& Barret 1990; Ryan \& Grolnick 1986; cited in Ryan and Deci 2000: 71). By encouraging choice making and acknowledging feelings and opportunities for self-direction, teachers can produce a greater feeling of autonomy in their students (Deci \& Ryan 1985). Dornyei (1994a: 282) outlines the following as ways in which teachers can promote learner autonomy in the classroom:

- $\quad$ Allowing real choices about alternative ways to achieve goal attainment.

- $\quad$ Minimizing external pressure and control.

- Sharing responsibilities with the students for organizing their time, effort and the learning process.

- Inviting students to design and prepare activities themselves and promoting peer teaching.

- $\quad$ Including project work where students are in charge.

- $\quad$ Giving students positions of genuine authority.

Researchers have found that "language programs that emphasize autonomy will likely foster student motivation and potential success" (Brookes and Grundy 1998; Dickenson 1995; Littlewood 1996,1999; cited in Noels et al. 2003: 53). However, it is not solely the responsibility of the language program to emphasize autonomy, but the teachers themselves must cultivate a learning environment where learner autonomy is encouraged and promoted. 


\subsection{Extrinsic and Instrumental Factors}

This section addresses how teachers can improve levels of motivation in the classroom by focusing on the following extrinsic and instrumental motivational factors respectively: internalization and promotion of the Ideal L2 Self.

\subsubsection{Internalization}

As outlined in section 2.3, Self-Determination Theory views extrinsic and intrinsic motivations not as categorically separate but rather as sitting at opposite ends of the same continuum of self-determination where extrinsic motivations become transformed into intrinsically, self-determined motives through the process of selfregulation (Noels et all. 2003). Therefore, it is possible that teachers can have a positive degree of influence on extrinsic factors of motivation in regards to the self-determination continuum. In other words, teachers can create the social conditions, which nurture the internalization and integration of extrinsically motivated behaviors in their students (Ryan and Deci 2000).

One way in which teachers can nurture the internalization process is through fostering a sense of relatedness in the classroom. Feelings of belonging and connectedness with others, in this case peers and the teacher, can facilitate internalization (Ryan and Deci 2000). In addition, teachers can further cultivate internalization by, "providing a meaningful rationale for an uninteresting behavior" (Ryan and Deci 2000: 74). As Noels et al. point out:

To foster sustained learning, it may not be sufficient to convince students that language learning is interesting and enjoyable; they may need to be persuaded that it is also personally important for them (2003: 52).

By doing so, teachers can set into motion the process of identified and integrated regulation (see section 2.3) (Ryan \& Deci 2000) within the student where internalization and integration has occurred.

\subsubsection{Promotion of the Ideal L2 Self}

Though the concept of the Ideal L2 Self is inherently integrative in nature (see 2.4 and 3.1), in order to promote images of the Ideal L2 Self in the classroom teachers must first speak to the instrumental orientation of students by showing them the potential usefulness of the L2 for both themselves and their community (Dornyei 1994a). As the perception of the L2 community has changed from national cultural identities to a global community of international L2 speakers, the need has arisen to broaden what comprises the content of Gardner's integrativeness (Csizer and Dornyei 2005). Csizer and Dornyei's (2005) proposed interpretation of integrativeness equates it (integrativeness) with Dornyei's Ideal L2 Self, which can be used to explain the motivational set-up in diverse learning contexts. However, this integrativeness is instrumentally fueled as Csizer and Dornyei note, "For many language learners it is the usefulness of L2 proficiency that provides the greatest driving force" (2005:21) in language learning and how that usefulness relates to the notion of the Ideal Self. By emphasizing the importance of English in the global community and the role international L2 speakers play in that community, teachers can tap into students' instrumental motivations to raise their awareness of their potential future role as English speakers in the globalized L2 community as well as to promote positive images of their Ideal L2 Self (Dornyei 1994a, Kormos and Csizer 2008).

\section{DISCUSSION: EXTENT OF INFLUENCE}

The above sections suggest that by focusing on certain motivational factors teachers can help improve levels of student motivation in an L2 learning environment. However, the extent to which teachers can improve levels of motivation greatly varies depending on factors outside of the teacher's control such as the learning context and the age group of the learners to name a few (Dornyei 1994a, Noels et al. 2003). However, within the classroom there are certainly actions teachers can take to cultivate student motivation to varying degrees in order to enhance their L2 learning. 
In regards to intrinsic motivation it would seem that the scope of a teacher's influence is great as the teacher has control over many of the factors which effect this type of motivation. From the materials and activities they select for the students to the type of social-contexts (classrooms) they create (which are aimed at cultivating confidence, competence and autonomy), teachers can play a central role in activating and sustaining students' intrinsic motivation, a motivation which is associated with positive L2 learning outcomes (see 4.1).

In regards to external factors, however, the teacher's influential range on motivation becomes more limited. Teachers, as with intrinsic motivation, can create classrooms that encourage the internalization of extrinsically motivated behaviors to take place. Additionally, teachers can stimulate students' ideas and image of the Ideal L2 Self through tapping into their instrumental orientations. However, compared with that of intrinsic motivation, the extent to which teachers can promote levels of motivation seems to be less.

\section{CONCLUSION}

Having examined the predominant motivational theories in the SLA literature the author was able to identify key factors that influence student motivation in language learning. Using this as a point of departure, the writer then went on to outline ways in which teachers can improve motivation levels in the classroom before addressing the extent to which these measures can effectively improve student motivation. It is clear that motivation plays a crucial role in foreign language learning and achievement, and as Oxford and Shearin (1994) observe, "Without knowing where the roots of motivation lie, how can teachers water the roots?" (p. 15). Therefore, understanding the constructs of this complex phenomenon puts educators in a better position to develop motivation in their students and "water the roots". However, the author would like to suggest that teachers not only focus on ways to improve levels of motivation in the classroom, but that they direct their efforts into sustaining students' motivational capacity as they strive for "excellence, autonomy and self-actualization" (Brown 2000: 165).

\section{ACKNOWLEDGMENT}

This work was supported by Hankuk University of Foreign Studies Research Fund 2012.

\section{AUTHOR INFORMATION}

Simon James Nicholson has been teaching EFL for nearly 12 years. He has lived and worked in India for five years and currently lives and works in Korea. He is a professor at the Hankuk University of Foreign Studies in South Korea where he teaches Practical English courses. The author may be contacted at: Hankuk University of Foreign Studies, Foreign Languages Education Center, 89 Wangsan-ri, Moheyon-myeon, Cheoin-gu, Yongin-si, Gyeonggido, Korea 449-791. E-mail: simonjamesnicholson@gmail.com

\section{REFERENCES}

1. Biehler, R. \& Snowman, J. (1997) 'Cognitive Views of Motivation'. In Snowman J., McCown, R.P. \& Biehler, R. (1997) Psychology Applied to Teaching. $8^{\text {th }}$ ed. Houghton Mifflin.

2. Brown, H.D. (2000) Principles of Language Learning and Teaching. $4^{\text {th }}$ ed. New York: Pearson Education.

3. Clement, R., Gardner, R.C., and Smythe P.C. (1977) 'Motivational variables in second language acquisition: a study of francophones learning English'. Canadian Journal of Behavioral Science 9: 123 133.

4. Clement, R. and Kruidenier, G.B. (1985) 'Aptitude, Attitude and Motivation in Second Language Proficiency: A Test of Clement's Model'. Journal of Language and Social Psychology 4/1: 21 - 37.

5. Crookes, G., \& Schmidt, R. (1991). 'Motivation: Reopening the research agenda'. Language Learning 41: 469-512.

6. Csizer, K. and Dornyei, Z. (2005) 'The Internal Structure of Language Learning Motivation and Its Relationship with Language Choice and Learning Effort'. The Modern Language Journal 89/1: 19 - 36.

7. Deci, E.L. (1975). Intrinsic motivation. New York: Plenum Publishing Co.

8. Deci, E. L., \& Ryan, R. M. (1985). Intrinsic motivation and self-determination in human behavior. New York: Plenum. 
9. Dev, P.C. (1997). 'Intrinsic motivation and academic achievement: What does their relationship imply for the classroom teacher?'. Remedial and Special Education 18/1: 12-19.

10. Dornyei, Z. (1994a) 'Motivation and Motivating in the Foreign Language Classroom.' The Modern Language Journal 78/3: 273 - 284.

11. Dornyei, Z. (1994b) 'Understanding L2 Motivation: On with the Challenge!'. The Modern Language Journal 78/4: $515-523$.

12. Dornyei, Z. (1998) 'Motivation in second and foreign language learning'. Language Teaching 31: 117 135 .

13. Dornyei, Z. (2001) Motivational Strategies in the Language Classroom. Cambridge University Press.

14. Dornyei, Z. (2003) Attitudes, Orientations, and Motivations in Language Learning: Advances in Theory, Research, and Applications. Oxford: Blackwell. 3 - 32.

15. Dornyei, Z. (2005) 'The Psychology of the Language Learner: Individual Differences Second Language Acquisition'. Lawrence Erlbaum Associates, Publishers Mahwah, N.J.

16. Dornyei, Z. (2007) 'Creating a Motivating Classroom Environment'. In Cummins, J. and Davison, C. (Eds.) (2007) International Handbook of English Language Teaching. New York: Springer.

17. Dornyei, Z. (2009) 'Psychology Matters'. In Breaven, B. (Ed.) IATEFL 2008: Exeter Conference Selections. Canterbury: IATEFL: $16-22$.

18. Gardner, R. C. (1985) Social Psychology and Second Language Learning: The Role of Attitudes and Motivation. London: Edward Arnold.

19. Gardner, R. and Lambert, W. (1959) 'Motivational Variables in Second-Language Acquisition'. Canadian Journal of Psychology 13/4: 266 - 272.

20. Gardner, R. and W. Lambert (1972) Attitudes and Motivation in Second-Language Learning. Rowley, Ma: Newbury House.

21. Gardner, R., P. Smythe, R. Clement, and L. Gliksman (1976) 'Second-Language learning: a socialpsychological perspective'. Canadian Modern Language Review 32: 198-213.

22. Kohn, A. (1993) Punished by rewards: The trouble with gold stars, incentive plans, A's, praise, and other bribes. Boston, MA: Houghton Mifflin.

23. Kormos, J. and Csizer, K. (2008) 'Age-Related Differences in the Motivation of Learning English as a Foreign Language: Attitudes, Selves, and Motivated Learning Behavior’. Language Learning 58/2: 327 355.

24. Lightbrown, P. and Spada, N. (2006) How Languages are Learned Oxford: Oxford University Press.

25. Liu, M. (2007) 'Chinese Students Motivation to Learn English at the Tertiary Level'. Asian EFL Journal 9/1: $126-146$.

26. Murray, G. (2011) 'Imagination, Metacognition and the L2 Self in a Self-Access Leaning Environment'. In Murray, Gao and Lamb (Eds) (2011) Identity, Motivation and Autonomy in Language Learning. Short Run Press Ltd.

27. Noels, K., Clement, R. and Pelletier, L. (1999) 'Perceptions of Teachers' Communicative Style and Students' Intrinsic and Extrinsic Motivation'. The Modern Language Journal 83/1: 23 - 34.

28. Noels, K.A., Clement, R., and Pelletier, A.G. (2001) 'Intrinsic, extrinsic, and integrative orientations of French Canadian learners of English'. The Canadian Language Review 57: 424-442.

29. Noels, K., Pelletier, L. and Clement, R. et al. (2003) 'Why Are You Learning a Second Language? Motivational Orientations and Self-Determination Theory'. Language Learning 53/1: 33 - 64.

30. Oxford, R. \& Shearin, J. (1994) 'Language Learning Motivation: Expanding the Theoretical Framework'. Modern Language Journal 78: 12-28.

31. Pae, T. (2008) 'Second Language Orientation and Self-Determination Theory: A Structural Analysis of the Factors Affecting Second Language Achievement'. Journal of Language and Social Psychology 27: 5 - 27.

32. Ramage, K. (1990) 'Motivational factors and persistence in foreign language study'. Language Learning 40: $189-219$.

33. Ryan, R.M. and Deci, E.L. (2000) 'Self-Determination Theory and the Facilitation of Intrinsic Motivation, Social Development, and Well-Being'. American Psychologist 55/1: 68 - 78.

34. Scheidecker, D. and Freeman, W. (1999) Bringing out the best in students: how legendary teachers motivate kids. London: SAGE.

35. Ushioda, E. (1996). Learner Autonomy. Dublin: Authentik. 
36. Ushioda, E. (2003) 'Motivation as a socially mediated process'. In D. Little, J. Ridley \& E. Ushioda (Eds.) (2003) Learner Autonomy in the Foreign Language Classroom: Teacher, Learner, Curriculum and Assessment. Dublin: Authentik.

37. Warden, C. and Lin, H.J. (2008) 'Existence of Integrative Motivation in an Asian EFL Setting'. Foreign Language Annals, 33/5: 535 - 545.

\section{NOTES}

